\title{
Sárkányok és kistigrisek ${ }^{2}$ - Kelet-Ázsia regionális fegyverkezési versenyének általános és országspecifikus jellemzői a Kínával kapcsolatos fenyegetettségpercepciójú országok esetében ${ }^{3} 2$.
}

\begin{abstract}
Kelet-Ázsia jelentős fegyverkezési folyamatoknak otthont adó régióvá vált az elmúlt évtizedekben. A szakirodalom sokat foglalkozik ennek kapcsán Kína és vele szemben az USA katonai képességeinek relatív erőviszonyaival. Jelen tanulmány célja bemutatni Kelet-Ázsia azon országainak haderőfejlesztéseit, amelyek valamilyen fenyegetettségpercepcióval rendelkeznének Kína kapcsán. A vizsgált adatok alapján látszik, hogy a 2008-2020 közötti időszakban jelentős fejlődést láthattunk mind a vizsgált fegyverrendszerek kvantitatív, mind kvalitatív vonatkozásaiban. A tanulmány második részében a vizsgált hét ország közül a négy délkelet-ázsiai (Vietnám, Malajzia, Fülöpszigetek és Indonézia) szereplöre vonatkozó trendeket láthatjuk, valamint az összes vizsgált országra vonatkozó általános trendek részletes elemzését.
\end{abstract}

Kulcsszavak: fegyverkezési verseny, Kelet-Ázsia, haditengerészet, A2/AD

\section{Dragons and Tigers Cubs - General and Country Specific Characteristics of East Asian Arms Race with a Case Study of Countries with Threat Perceptions Regarding China 2}

The region of East Asia has become host of a significant armaments trend. Relevant literature has given much attention to the changes in relative power between China and the United States. This paper aims to present general and specific quantifiable trends in the development of military capabilities of East Asian states that have security concerns regarding China. The conclusion of the processed data shows that between 2008 and 2020, the studied actors have conducted significant development of relevant naval and maritime capabilities both in quantitative and qualitative terms. This second part of the paper will provide an overview on the four Southeast Asian countries examined during the research project, as well as the analysis of general trends regarding the seven actors and their defence development efforts.

Keywords: arms race, East Asia, naval power, A2/AD

Bartók András a Nemzeti Közszolgálati Egyetem Államtudományi és Nemzetközi Tanulmányok Kar Nemzetközi Kapcsolatok és Diplomácia Tanszék tanársegédje. E-mail: bartok.andras@uni-nke.hu

2 A „sárkány” több kelet-ázsiai haditengerészet hagyományában utal a hadihajókra, vagy a haditengerészeti szolgálatokhoz kötődő általános mitikus motívum. Például a japán haditengerészet máig használt indulója a „tenger acélsárkányainak” nevezi hadihajóit. Délkelet-Ázsia országai esetében a tigris fontos motívuma általánosságban a fegyveres erőknek. A tanulmány az Innovációs és Technológiai Minisztérium ÚNKP-19-3-III-NKE-91 kódszámú Új Nemzeti Kiválóság Programjának szakmai támogatásával készült. 


\section{Bevezetés}

A tanulmány előző részében láthattuk, hogy a kínai $\mathrm{A} 2 / \mathrm{AD}$ fejlesztések jellegzetességeire építve, milyen szempontok mentén érdemes megfigyelni a kínai képességek növekedésére adott válaszreakciókat, ha szintén a tengeri terület-megtagadás múveleti koncepciójában érdekelt felek védelempolitikáira vagyunk kíváncsiak. Az előzőekben a hét vizsgált ország közül a három északkelet-ázsiai szereplö - Japán, Dél-Korea, Tajvan - részletesebb bemutatását láthattuk, ezt követi majd a továbbiakban a négy délkelet-ázsiai szereplő törekvéseinek áttekintése.

Ezt követően a felhasznált források alapján az összesített adatokban látható trendek részletesebb elemzését olvashatjuk a kétrészes tanulmány végkövetkeztetéseiként.

\section{Vietnám}

Vietnám a posztbipoláris korszakban párhuzamosan igyekezett normalizálni külkapcsolatait úgy Kínával, mint az Amerikai Egyesült Államokkal, illetve biztonságpolitikájában ellensúlyozni a kínai fél katonai képességeinek növekedését a dél-kínai-tengeri térségben (1. táblázat).

\section{1. táblázat: Vietnám vonatkozó védelmi képességei 2008-2020}

\begin{tabular}{|c|c|c|c|c|c|c|c|c|c|c|c|c|c|}
\hline & 2008 & 2009 & 2010 & 2011 & 2012 & 2013 & 2014 & 2015 & 2016 & 2017 & 2018 & 2019 & 2020 \\
\hline Állomány (fö) & 40000 & 40000 & 40000 & 40000 & 40000 & 40000 & 40000 & 40000 & 40000 & 40000 & 40000 & 40000 & 40000 \\
\hline Cirkáló $(\mathrm{db})$ & 0 & 0 & 0 & 0 & 0 & 0 & 0 & 0 & 0 & 0 & 0 & 0 & 0 \\
\hline Romboló (db) & 0 & 0 & 0 & 0 & 0 & 0 & 0 & 0 & 0 & 0 & 0 & 0 & 0 \\
\hline Fregatt $(\mathrm{db})$ & 5 & 5 & 5 & 0 & 2 & 2 & 2 & 2 & 2 & 2 & 2 & 4 & 4 \\
\hline Korvett $(\mathrm{db})$ & 6 & 6 & 6 & 7 & 7 & 6 & 6 & 6 & 6 & 6 & 6 & 6 & 8 \\
\hline $\begin{array}{l}\text { Támadó tengeralattjáró (hagyo- } \\
\text { mányos meghajtású) (db) }\end{array}$ & 2 & 2 & 2 & 2 & 2 & 2 & 2 & 4 & 6 & 6 & 8 & 8 & 8 \\
\hline Vadászgépek, vadászbombázók (db) & 204 & 204 & 204 & 219 & 231 & 97 & 97 & 97 & 101 & 107 & 74 & 73 & 72 \\
\hline $\begin{array}{l}\text { Tengeralattjáró elleni hadviselésre } \\
\text { alkalmas repülőeszközök (merev- } \\
\text { szárnyak/ forgószárnyak) (db) }\end{array}$ & 17 & 17 & 17 & 17 & 17 & 10 & 10 & 10 & 10 & 10 & 10 & 10 & 10 \\
\hline $\begin{array}{l}\text { Parti őrség hajóegységeinek } \\
\text { száma (db) }\end{array}$ & - & - & - & - & - & 32 & 32 & 37 & 40 & 56 & 69 & 69 & 69 \\
\hline
\end{tabular}

Forrás: a szerző szerkesztése az International Institute of Strategic Studies: The Military Balance évkönyvek (2008-2020) adatainak összesítése alapján

A kínai-vietnámi háború során (1978-1979) és azt követően Peking fokozatosan szorította ki Hanoit a Paracell-szigetcsoporton található pozícióiból, míg végül a szigetcsoport egésze kínai fennhatóság alá került. A 2000-es évek után jelentős konfrontációk alakultak ki, egyrészt a felek kizárólagos gazdasági övezeteinek átfedései, ${ }^{4}$ valamint a Spratlyszigetcsoporton zajló kínai mesterséges szigetek építése miatt.

4 Példaként említhetjük erre az egyensúlyozásra, hogy miközben 2014-ben komoly incidensek alakultak ki egy a vietnámi vizeken felbukkant kínai olajfúrótorony kapcsán, Hanoi emellett is csatlakozott a kínai vezetésű Ázsiai Infrastrukturális és Beruházási Bankhoz, lásd The Saigon Times: Vietnam joins AIIB to seek new funding source. [online], 2015. 06. 30. Forrás: english.thesaigontimes.vn [2021. 04. 13.] 
Vietnám ennek megfelelően egyszerre igyekszik pozitív gazdasági kapcsolatokat ápolni a politikai ideológiailag hozzá közelebb álló Kínai Népköztársasággal, de közben javítani katonai képességeit, amelyekkel próbálja elrettenteni hatalmas északi szomszédja további terjeszkedő ambícióit.

Vietnám a többi vizsgált országhoz képest némileg óvatosabban fogalmazza meg fenyegetettségpercepcióit Kína vonatkozásában, a 2019-es védelmi Fehér könyv a vietnámi és kínai területi követelések „ellentéteit” említi. ${ }^{5}$ A nagyhatalmak közötti ellensúlyozást illusztrálja továbbá, hogy bár Vietnám védelempolitikájának fontos alapvetése, hogy nem köt katonai szövetséget, korlátozott mértékben mégis teret enged védelmi együttműködéseknek, ha a körülmények úgy kívánják. Hanoi az elmúlt években egyrészt jelentős fegyverimportőre volt az orosz haditechnikának, illetve számos együttmüködés felé mutató lépést tett az Egyesült Államok, ${ }^{6}$ Japán, ${ }^{7}$ illetve többek között Ausztrália felé is. ${ }^{8}$

Vietnám az elmúlt évtizedekben átfogó haderöreformba kezdett. Ennek kiemelt eleme a tengeri dimenzióból érkező fenyegetésekkel szembeni elrettentési képességek javítása. Az ország az elmúlt években ambiciózus haderőfejlesztési programot végez, amelynek láthatóan központi elemét képezi a tengeri védelmi képességek fejlesztése. Az ország hadereje a hidegháborús, nagyhatalmakkal szembeni aszimmetrikus konfliktusok sikereit követően jelentős technológiai lemaradást halmozott fel, ennek kiküszöbölése föként az ezredfordulót követően tudott megindulni. Mára Vietnám Délkelet-Ázsia egyik legerősebb regionális katonai hatalma.

A fejlesztések és új eszközök hadrendbe állítása rengeteg párhuzamot mutat a kínai A2/AD koncepció elemeivel, csak épp ebben az esetben a feltételezhető kihívást maga Kína jelenti. Az első lépést, a kínai mintához hasonlóan, a hajó elleni cirkálórakéták hadrendbe állítása jelentette. Hanoi a 2000-es évek elején indult beszerzések keretében három orosz gyártmányú hajó elleni rakétatípussal (SSC-1, SSC-3 és SSC-5) biztosította A2/AD csapásmérő rendszere szárazföldi komponensét.

Korábbi képességeihez mérten a vizsgált időszakban hatalmas fejlődésen esett át az ország haditengerészete is. A tengeralattjáró-park 2008-ban 2 db, kiképzési célokra alkalmas Yugo osztályú „törpe” tengeralattjáróból állt, a 2010-es években azonban 6 db Kilo osztályú támadó tengeralattjárót vásárolt Oroszországtól és állított hadrendbe. Felszíni flottája 2008-ban 5 db, az 1960-as évek technológiai színvonalát jelentő, szovjet gyártmányú Petya II/III osztályú fregattból, illetve 6 db szintén elavult korvettből állt. A Petya hajóosztály egységeit 2011 után a korszerü, orosz Gepard osztályú fregattokkal tudta leváltani, jelenleg $4 \mathrm{db}$ egység áll hadrendben. Szintén jelentős korszerüsítésen estek át a korvettek, amelyek között az orosz/szovjet típusok mellett már dél-koreai eredetű egységek is megjelentek.

The Socialist Republic of Vietnam: Viet Nam National Defense WHITE PAPER 2019. [online], 2019. 12. 20. Forrás: news.chinhphu.vn [2021. 04. 13.]

6 Bac Pham - Chris Humphrey: US navy aircraft carrier Theodore Roosevelt to visit Vietnam as South China Sea tensions simmer. [online], 2020. 03. 04. Forrás: scmp.com [2021. 04. 13.]

The Japan Times: Japan and Vietnam ink first maritime patrol ship deal. [online], 2020. 08. 11. Forrás: japantimes.com. jp [2021. 04. 13.]

8 Prashanth Parameswaran: Defense Policy Dialogue Highlihgt Vietnam-Australia security ties. [online], 2019. 11. 04. Forrás: thediplomat.com [2021. 04. 13.] 
A fedélzeti fegyverzet pedig nagyobb hatótávolságú és korszerủbb hajó elleni és légvédelmi rakétákkal erősödött. ${ }^{9}$

Vietnám együttműködési körének bővülésére jó példa a járőrrepülő, ASW-eszközpark és partiőrségi hajóparkjának korszerüsítése, ennek fő beszállítói ugyanis az Egyesült Államok és Japán. ${ }^{10} \mathrm{Az}$ ASW-rendeltetésű eszközök száma ugyan összességében csökkent, de a géptípusokat tekintve ez lényegében az elavult Be-12 Chayka repülőgép kivonását jelentette. 2008-ban a haditengerészetnek nem volt olyan felszíni hadihajója, amely alkalmas lett volna ASW-helikopterek üzemeltetésére, ma már viszont Vietnám mind a négy fregattja rendelkezik ezzel a képességgel, nagyban kiterjesztve a tengeralattjáró elleni hadviselés hatótávolságát.

Vietnám vadász- és vadászbombázó gépeinek száma jelentősen csökkent, mivel a reménytelenül elavult géptípusok és eszközök kivonása elkerülhetetlen volt. Ezt némileg ellensúlyozandó, korszerübb orosz típusok álltak hadrendbe, bár jóval kisebb számban, mint a leszerelt MiG-21 flotta (2. táblázat).

\section{2. táblázat: Vietnám vadászgép-, vadászbombázó- és ASW-eszközparkjának típusai 2008-ban és 2020-ban}

\begin{tabular}{|l|r|c|}
\hline Vietnám & $\mathbf{2 0 0 8}$ & $\mathbf{2 0 2 0}$ \\
\hline MiG-21 & 140 & \\
\hline Su-22 & 53 & 26 \\
\hline Su-27 & 0 & 11 \\
\hline Su-30 & 4 & 35 \\
\hline Ka-28 & 10 & 10 \\
\hline
\end{tabular}

Forrás: a szerző szerkesztése az International Institute of Strategic Studies: The Military Balance évkönyvek

(2008-2020) adatainak összesítése alapján

Összességében Vietnám esetében a legjelentősebb arányaiban a vonatkozó képességek számbeli, illetve azok technológiai színvonalának minőségi fejlesztései. Hanoi láthatóan igyekszik emulálni a kínai A2/AD koncepció főbb elemeit. ${ }^{11}$

\section{Fülöp-szigetek}

A Fülöp-szigetek védelempolitikájának erőforrásait jelentős mértékben lekötik különféle belbiztonsági, felkelőkkel és terroristaszervezetekkel szembeni feladatkörök, így a haderő klasszikus területvédelmi, illetve haditengerészeti képességei a legelmaradottabbak a vizsgált országok közül (3. táblázat).

\footnotetext{
Defense World: Vietnam Launches Two Home-made Molniya-class Missile Corvettes. [online], 2017. 10. 12. Forrás: defenseworld.net [2021. 04. 13.]

10 Wyatt Olson: US to give Vietnam another coast guard cutter amid rising tensions in South China Sea. [online], 2019. 11. 21. Forrás: stripes.com [2021. 04. 13.]

11 Felix K. Chang: Resist and Reward: Vietnam's Naval Expansion. [online], 2019. 11. 06. Forrás: fpri.org [2021. 04. 13.]
} 
3. táblázat: A Fülöp-szigetek vonatkozó védelmi képességei 2008-2020

\begin{tabular}{|c|c|c|c|c|c|c|c|c|c|c|c|c|c|}
\hline & 2008 & 2009 & 2010 & 2011 & 2012 & 2013 & 2014 & 2015 & 2016 & 2017 & 2018 & 2019 & 2020 \\
\hline Állomány (fö) & 24000 & 24000 & 24000 & 24000 & 24000 & 24000 & 24000 & 24000 & 24000 & 24000 & 24000 & 23750 & 23750 \\
\hline Cirkáló (db) & 0 & 0 & 0 & 0 & 0 & 0 & 0 & 0 & 0 & 0 & 0 & 0 & 0 \\
\hline Romboló (db) & 0 & 0 & 0 & 0 & 0 & 0 & 0 & 0 & 0 & 0 & 0 & 0 & 0 \\
\hline Fregatt $(\mathrm{db})$ & 1 & 1 & 1 & 1 & 1 & 1 & 1 & 1 & 1 & 1 & 1 & 0 & 0 \\
\hline Korvett $(\mathrm{db})$ & 0 & 0 & 0 & 0 & 0 & 0 & 0 & 0 & 0 & 0 & 0 & 0 & 1 \\
\hline $\begin{array}{l}\text { Támadó tengeralattjáró (hagyo- } \\
\text { mányos meghajtású) }(\mathrm{db})\end{array}$ & 0 & 0 & 0 & 0 & 0 & 0 & 0 & 0 & 0 & 0 & 0 & 0 & 0 \\
\hline Vadászgépek, vadászbombázók (db) & 15 & 15 & 15 & 7 & 6 & 11 & 10 & 10 & 10 & 12 & 22 & 22 & 21 \\
\hline $\begin{array}{l}\text { Tengeralattjáró elleni hadviselésre } \\
\text { alkalmas repülőeszközök (merev- } \\
\text { szárnyak/ forgószárnyak) (db) }\end{array}$ & 0 & 0 & 0 & 0 & 0 & 0 & 0 & 0 & 0 & 0 & 0 & 0 & 2 \\
\hline $\begin{array}{l}\text { Parti őrség hajóegységeinek } \\
\text { száma (db) }\end{array}$ & 61 & 61 & 51 & 61 & 61 & 57 & 58 & 58 & 72 & 72 & 78 & 84 & 86 \\
\hline
\end{tabular}

Forrás: a szerző szerkesztése az International Institute of Strategic Studies: The Military Balance évkönyvek (2008-2020) adatainak összesítése alapján

Manila külpolitikájában szintén nyomon követhető bizonyos egyensúlyozás a nagyhatalmak között. Az ország a hidegháború óta az USA szövetségese, ám az amerikai katonai jelenlét keretrendszere a posztbipoláris korszakban megváltozott, 1992 végére az amerikai bázisokat bezárták, a csapatokat kivonták. Az új szövetségi keretrendszerben az Egyesült Államoknak a Fülöp-szigeteki vezetés meghívásával továbbra is lehetősége van katonai jelenlétet fenntartani a szigetországban - ennek legfontosabb eleme a Subi öbölben található hadikikötő használata 2012 óta -, ám ez jóval kisebb katonai jelenlétet jelent, mint a hidegháború idején.

A Fülöp-szigetek igyekszik jó gazdasági kapcsolatokat ápolni Kínával, biztonsága számára azonban Peking komoly kihívást jelent, mivel annak dél-kínai-tengeri területi követelései számos ponton ütköznek a Fülöp-szigetek érdekeivel. ${ }^{12}$ Összességében elmondható, hogy a jelenlegi Duterte-kormány egyszerre igyekszik a diplomáciai kapcsolatok szintjén enyhíteni a dél-kínai-tengeri viták jelentette feszültségeket, főként a Kínához füződő gazdasági kapcsolatok miatt, miközben biztonság- és védelempolitikájában igyekszik javítani területvédelmi és érdekérvényesítő képességein. Utóbbinak része egyrészt katonai képességeinek javítása, illetve nemzetközi biztonsági együttmüködések kiépítése és bővítése, például Japánnal. ${ }^{13}$

A Fülöp-szigetek többször is kísérletet tett területvédelmi képességeinek javítására, ám a védelmi reformok 1995-ös meghirdetésétől egészen 2012-ig nem sikerült érdemi előrelépést elérni, ezért 2013-ban Manila egy 15 éves program keretében új haderőfejlesztési politikát hirdetett. ${ }^{14}$ Bár a szigetország eszközrendszere mind kvalitatív, mind kvantitatív

12 A dél-kínai területvita Fülöp-szigetekhez kötődő vonatkozásaival kapcsolatban lásd Peragovics Tamás. Új status quo a Dél-kínai-tengeren?: Kína mesterségessziget-építésének hatásai a régió biztonságára. Nemzet és Biztonság, 10. (2016), 3. 58-74.; Adam Stempler: The South China Sea Dispute between China and the Philippines. In Olga Barbasiewicz - Marcin Grabowski - Ewa Trojnar: Security dilemmas and challenges in $21^{\text {st }}$ century Asia. Berlin, Peter Lang, 2020.

13 Bjørn Elias Mikalsen Grønning: Japan's security cooperation with the Philippines and Vietnam. The Pacific Review, 31. (2018), 4. 533-552.

14 Department of National Defense of the Philippines: Revised Armed Forces of the Philippines Modernization Act. [online], Forrás: dnd.gov.ph [2021. 04. 13.] 
szempontból jóval elmaradottabb, mint a tanulmányban vizsgált további országoké, a regionális mintázathoz illeszkedik abban, hogy a legújabb haderőfejlesztési törekvéseiben kiemelt szerepet kap a tengeri érdekek megvédésének képessége.

A Fülöp-szigetek haditengerészeti erőkivetítési képességei lényegében nem léteznek. Felszíni flottájának egyetlen nagyobb méretű hajója sokáig a BRP Rajah Humabon nevü fregatt volt, amely az Egyesült Államok Haditengerészetében szolgált a II. világháborúban, amit a háború után előbb 20 évre Japán, majd a Fülöp-szigetek kapott meg. Az egység ennek megfelelően nem rendelkezett naprakésznek tekinthető fegyverzettel (csak csöves eszközök, rakéták nem), végül 2018-ban leszerelték. ${ }^{15}$ Manila haderőfejlesztési programja keretében számos korszerü felszíni hajóegységet készül hadrendbe állítani a következő években. Ezek közül az első, a dél-koreai Phoang osztályú BRP Conrado Yap (PS-39) korvett 2019-ben állt hadrendbe. ${ }^{16}$ Egy évvel később állt szolgálatba a szintén Dél-Koreából vásárolt Jose Rizal osztály névadó egysége. Az új fregatt, amelynek testvérhajója várhatóan 2021-ben áll szolgálatba. A korszerü hajó elleni és légvédelmi fegyverzettel, valamint jelentős ASW-fegyverzettel - köztük fedélzeti helikopterrel is - rendelkező típus ugrásszerüen növelte Manila haditengerészeti képességeit. ${ }^{17}$ A Fülöp-szigetek, kiküszöbölendő a jelenlegi müveleti hiányosságot, francia Scorpene osztályú támadó tengeralattjárók beszerzését is tervezi. ${ }^{18}$

Szintén zajló folyamat a járőrözési képességek fejlesztése. A Fülöp-szigetek bővíti a járőrrepülőgép és -tengeralattjáró elleni hadviselésre alkalmas repülőgép-eszközparkját, AW 159 Wildcat ASW-helikopterek hadrendbe állításával. ${ }^{19}$

A vizsgált időszakban jelentős növekedést összességében a partiőrségi hajóegysége száma mutatott, Manila 61-ről 86-ra növelte aktív hajóegységeinek számát. Ami ugyanakkor még mindig nagyon kevés annak függvényében, hogy a szigetországnak több mint 36 ezer kilométeres partvonalat kell megoltalmaznia. ${ }^{20}$

A Fülöp-szigetek alig rendelkezett (rendelkezik) érdemi vadász- és vadászbombázórepülögép-flottával, 2008-ban mindössze $15 \mathrm{db}$ OV-10 Bronco állt hadrendben. Ezek az 1960-as évek technikai színvolán álló könnyü csapásmérő repülőgépek napjainkra teljesen elavultak, lényegében csak könnyü fegyverzetü felekelö erők ellen alkalmazhatók hatásosan. Hogy érdemi légiharcképességekre is szert tegyen, Manila dél-koreai gyártmányú FA-50 könnyü vadász- és csapásmérőgépeket állított hadrendbe. ${ }^{21} \mathrm{Az}$ eredetileg kiképzési célra kifejlesztett típus képességeit azonban jelentősen felülmúlják a térség többi országa által hadrendben tartott „valódi” vadász- és csapásmérő típusok (4. táblázat).

15 Priam Nepomuceno: WW2-era BRP Rajah Humabon to be turned into a museum exhibit. [online], 2018. 03. 16. Forrás: pna.gov.ph [2021. 04. 13.]

16 Navy Recognition: Navy of Philippines will order two new Pohang-class corvettes from South Korea. [online], 2019. 08. Forrás: navyrecognition.com [2021.04. 13.]

17 Naval Technology: Jose Rizal-Class Frigates, Philippines. [online], Forrás: navaltechnology.com [2021. 04. 13.]

18 Priam Nepomuceno: Submarine acquisition among Navy's priorities. [online], 2020. 03. 04. Forrás: pna.gov.ph [2021. 04. 13.]

19 Priam Nepomuceno: Navy's anti-sub choppers to be operational in November. [online], 2020. 01. 16. Forrás: pna.gov.ph [2021. 04. 13.]

20 CIA The World Factbook: The Philippines. [online], 2021. 06. 29. Forrás: cia.gov [2021. 04. 13.]

${ }^{21}$ Airforce Technology: FA-50 Light Combat Aircraft. [online], Forrás: airforce-technology.com [2021. 04. 13.] 


\section{4. táblázat: A Fülöp-szigetek vadászgép-, vadászbombázó- és ASW-eszközparkjának típusai 2008-ban és 2020-ban}

\begin{tabular}{|l|c|c|}
\hline Fülöp-szigetek & $\mathbf{2 0 0 8}$ & $\mathbf{2 0 2 0}$ \\
\hline FA-50 & & 12 \\
\hline OV-10 Bronco & 15 & 9 \\
\hline AW159 & 0 & 2 \\
\hline
\end{tabular}

Forrás: a szerző szerkesztése az International Institute of Strategic Studies: The Military Balance évkönyvek (2008-2020) adatainak összesítése alapján

A csekély haditengerészeti eszközpark és ASW-képességek, illetve a teljesen hiányzó tengeri járőrrepülőgépek komoly kihívást jelent az észlelési képességek szempontjából. Az ország fegyveres erőinek legfontosabb feladata a jelenleg is aktív felkelőkkel és terroristamozgalmakkal szembeni fellépés, illetve az ezzel szoros összefüggésben levő regionális kalóztevékenység. Ennek fényében érthető, hogy a filippínó fegyveres erőkön belül a külső fenyegetésekkel szembeni védelem kérdései csupán az elmúlt években tudtak magasabb prioritásra emelkedni.

\section{Malajzia}

Malajzia védelempolitikájában a Fülöp-szigetekéhez hasonló motívum, hogy a gyarmati státuszból való felszabadulást követően a fegyveres erők fö feladata sokáig a különféle felkelőcsoportok elleni küzdelem volt. Az ország jelentős mértékben érintett a dél-kínai-tengeri szigetvitában, komoly gazdasági érdeke füződik az ott található energiahordozókhoz való hozzáféréshez és az utóbbi években egyre többször konfrontálódott Pekinggel. Más, a vitában részes államokhoz - például Vietnámhoz - képest azonban jóval elmaradottabbak haditengerészeti érdekérvényesítő képességei, bár nem olyan mértékben, mint azt a Fülöp-szigeteknél láthattuk (5. táblázat).

\section{5. táblázat: Malajzia vonatkozó védelmi képességei 2008-2020}

\begin{tabular}{|c|c|c|c|c|c|c|c|c|c|c|c|c|c|}
\hline & 2008 & 2009 & 2010 & 2011 & 2012 & 2013 & 2014 & 2015 & 2016 & 2017 & 2018 & 2019 & 2020 \\
\hline Állomány (fö) & 14000 & 14000 & 14000 & 14000 & 14000 & 14000 & 14000 & 14000 & 14000 & 14000 & 14000 & 18000 & 18000 \\
\hline Cirkáló (db) & 0 & 0 & 0 & 0 & 0 & 0 & 0 & 0 & 0 & 0 & 0 & 0 & 0 \\
\hline Romboló (db) & 0 & 0 & 0 & 0 & 0 & 0 & 0 & 0 & 0 & 0 & 0 & 0 & 0 \\
\hline Fregatt $(\mathrm{db})$ & 3 & 2 & 2 & 8 & 10 & 10 & 10 & 10 & 10 & 10 & 10 & 10 & 10 \\
\hline Korvett $(\mathrm{db})$ & 8 & 8 & 10 & 4 & 4 & 4 & 4 & 4 & 4 & 4 & 4 & 4 & 4 \\
\hline $\begin{array}{l}\text { Támadó tengeralattjáró (hagyo- } \\
\text { mányos meghajtású) (db) }\end{array}$ & 0 & 1 & 2 & 2 & 2 & 2 & 2 & 2 & 2 & 2 & 2 & 2 & 2 \\
\hline Vadászgépek, vadászbombázók (db) & 68 & 65 & 59 & 59 & 47 & 47 & 47 & 47 & 47 & 47 & 47 & 47 & 36 \\
\hline $\begin{array}{l}\text { Tengeralattjáró elleni hadviselésre } \\
\text { alkalmas repülőeszközök (merev- } \\
\text { szárnyak/ forgószárnyak) (db) }\end{array}$ & 32 & 26 & 26 & 6 & 6 & 6 & 6 & 6 & 6 & 6 & 6 & 6 & 6 \\
\hline $\begin{array}{l}\text { Parti őrség hajóegységeinek } \\
\text { száma (db) }\end{array}$ & 40 & 40 & 51 & 66 & 66 & 84 & 189 & 189 & 191 & 185 & 129 & 130 & 127 \\
\hline
\end{tabular}

Forrás: a szerző szerkesztése az International Institute of Strategic Studies: The Military Balance évkönyvek (2008-2020) adatainak összesítése alapján 
A Fülöp-szigetekkel ellentétben Malajzia a hidegháborút követő időszakban képes volt érdemi haderőfejlesztési programokat megvalósítani, amelyek javították a területvédelmi képességeit, ami annak is volt köszönhető, hogy a szeparatista mozgalmak jelentette fenyegetés az 1990-es évek eleje óta nem számottevő.

Malajzia 2020-ban hirdette meg eddigi legátfogóbb haderöreform-programját, ami 2020-tól 2030-ig a haderő átfogó átszervezését, müveleti képességeinek javítását, valamint az ország hadiiparának fejlesztését tüzte ki célul. Mivel Kuala Lumpur egyre nagyobb fenyegetésként értékeli a tengeri kihívásokat, így a haditengerészeti képességek fejlesztése magas prioritást élvez. ${ }^{22}$

Az ország haditengerészete a vizsgált időszakban - képességeit tekintve - jelentősen megerősödött. 2008-ban felszíni hajóinak gerincét három fregatt és nyolc korvett alkotta, 2020-ban pedig tíz fregatt és négy korvett állt hadrendben. A brit gyártású Leiku osztály két fregattja az 1990-es években állt hadrendbe. A típus hajó elleni és légvédelmi rakétáival, illetve ASW-fegyverzetével - közte egy fedélzeti helikopterrel - komoly előrelépést jelentett Malajzia haditengerészete számára. ${ }^{23}$

A következő generációt a német gyártmányú Kedah osztály hat hajóegysége jelenti, amelyek 2006 és 2010 között álltak hadrendbe. A Kedah osztályt eredetileg 27 egységre tervezték, de költségvetési okokból csak hat épült meg. Szintén pénzügyi okokból a hadrendbe álló hat egység - noha a lehetőséget kialakították - végül nem kapott rakétafegyverzetet. A két fedélzeti löveggel, illetve egy helikopterrel felszerelt típus így inkább csak őrhajóként használható. Ezt a hiányosságot a saját gyártású, de francia tervek alapján épülő Maharaja Lela osztályú part menti hadihajók (fregattok/őrhajók) fogják pótolni, amelyek - legalább is a tervek szerint korszerü hajó elleni és légvédelmi rakétákat fognak kapni. $^{24} \mathrm{~A}$ korvettek esetében szintén olyan új típusok rendszeresítése, illetve korábbi típusok átfogó korszerüsítése zajlott, amelyeknek köszönhetően jelentősen bővült azok légvédelmi képessége. A 2000-es években zajló flottafejlesztési törekvések keretében Kuala Lumpur két francia gyártású, Scorpéne osztályú tengeralattjárót is vásárolt, amelyek 2009-ben álltak hadrendbe. ${ }^{25}$

A számottevő eredmények ellenére azonban Malajzia számára kihívást jelent a haditengerészeti képességrendszerében a járőrözéshez szükséges repülőgépek alacsony száma, valamint a tengeralattjáró elleni hadviselésre alkalmas repülőeszközök alacsony száma, a mindössze 6 db Lynx helikopter. Ezt a lemaradást hivatott javítani a haderöreform következő ciklusában tervezett jelentősebb beszerzési program, aminek keretében hagyományos és pilóta nélküli tengeri járör repülőgépek hadrendbe állítását tervezik. ${ }^{26}$

Malajzia vadász- és vadászbombázó repülőgépeinek száma nagymértékben csökkent 2008 és 2020 között, itt is főként az elavult típusok fokozatos kivonása miatt. Bár ma már néhány korszerübb típus is része az eszközparknak, a korszerűtlen gépek leszerelését

\footnotetext{
22 Mike Yeo. Malaysia points to top concerns in first-ever defense whitepaper. [online], 2019. 12. 03. Forrás: defensenews. com [2021. 04. 13.]

23 Stephen Saunders: Jane's Fighting Ships 2009-2010. Coulsdon, Surrey, UK, IHS Jane’s, 2009. 494.

24 Naval Technology: Maharaja Lela Class Littoral Combat Ships. [online], é. n. Forrás: naval-technology.com

25 Naval Technology (é. n.) i. m. 493-497.

26 Mike Yeo: Malaysia to launch competition for drones and manned maritime patrol aircraft. [online], 2020. 08. 25. Forrás: defensenews.com [2021. 04. 13.]
} 
egyelöre nem követte érdemben a modernebb típusok számának jelentős növekedése (6. táblázat).

6. táblázat: Malajzia vadászgép-, vadászbombázó- és ASW-eszközparkjának típusai 2008-ban és 2020-ban

\begin{tabular}{|l|r|r|}
\hline Malajzia & $\mathbf{2 0 0 8}$ & $\mathbf{2 0 2 0}$ \\
\hline Mk108 Hawk & 8 & 0 \\
\hline F-5 & 15 & 8 \\
\hline MiG-29 & 16 & 10 \\
\hline F-18 & 8 & 8 \\
\hline Su-30 & 18 & 18 \\
\hline Super Lynx 300 & 6 & 6 \\
\hline
\end{tabular}

Forrás: a szerző szerkesztése az International Institute of Strategic Studies: The Military Balance évkönyvek (2008-2020) adatainak összesítése alapján

\section{Indonézia}

Indonézia érintettsége a dél-kínai-tengeri feszültséggóc kapcsán sajátos, ugyanis az ország hivatalosan nem tekinti magát részes államnak. Azonban a kínai „kilenc pontos” követelés által rajzolt zóna magában foglalja az Indonéziához tartozó Natuna-szigeteket, illetve az ezekhez tartozó vízterületet, amelyet Indonézia „Natuna-tengerként” azonosít. Így bár formálisan nem a dél-kínai-tengeri szigetviták kapcsán, de Jakarta mégis érintett fél a kínai érdekérvényesítési törekvések vonatkozásában (7. táblázat).

\section{7. táblázat: Indonézia vonatkozó védelmi képességei 2008-2020}

\begin{tabular}{|c|c|c|c|c|c|c|c|c|c|c|c|c|c|}
\hline & 2008 & 2009 & 2010 & 2011 & 2012 & 2013 & 2014 & 2015 & 2016 & 2017 & 2018 & 2019 & 2020 \\
\hline Állomány (fö) & 45000 & 45000 & 45000 & 45000 & 45000 & 65000 & 65000 & 65000 & 65000 & 65000 & 65000 & 65000 & 65000 \\
\hline Cirkáló (db) & 0 & 0 & 0 & 0 & 0 & 0 & 0 & 0 & 0 & 0 & 0 & 0 & 0 \\
\hline Romboló (db) & 0 & 0 & 0 & 0 & 0 & 0 & 0 & 0 & 0 & 0 & 0 & 0 & 0 \\
\hline Fregatt $(\mathrm{db})$ & 8 & 8 & 7 & 11 & 11 & 11 & 11 & 11 & 12 & 13 & 13 & 13 & 13 \\
\hline Korvett $(\mathrm{db})$ & 21 & 21 & 23 & 19 & 19 & 19 & 18 & 18 & 21 & 20 & 20 & 20 & 20 \\
\hline $\begin{array}{l}\text { Támadó tengeralattjáró (hagyo- } \\
\text { mányos meghajtású) }(\mathrm{db})\end{array}$ & 2 & 2 & 2 & 2 & 2 & 2 & 2 & 2 & 2 & 2 & 3 & 4 & 4 \\
\hline Vadászgépek, vadászbombázók (db) & 72 & 72 & 74 & 46 & 32 & 32 & 38 & 43 & 46 & 51 & 42 & 49 & 49 \\
\hline $\begin{array}{l}\text { Tengeralattjáró elleni hadviselésre } \\
\text { alkalmas repülőeszközök (merev- } \\
\text { szárnyak/ forgószárnyak) (db) }\end{array}$ & 9 & 9 & 9 & 9 & 0 & 0 & 0 & 0 & 0 & 0 & 0 & 4 & 4 \\
\hline $\begin{array}{l}\text { Parti őrség hajóegységeinek } \\
\text { száma (db) }\end{array}$ & 85 & 85 & 85 & 28 & 28 & 36 & 37 & 37 & 34 & 31 & 31 & 38 & 38 \\
\hline
\end{tabular}

Forrás: a szerző szerkesztése az International Institute of Strategic Studies: The Military Balance évkönyvek (2008-2020) adatainak összesítése alapján

Indonézia külpolitikai hagyományainak része a semleges álláspont képviselete, ezzel együtt is a többi országhoz hasonló módon igyekszik stratégiáját a tengeri elrettentés szükségletéhez igazítani.

Az ország 2014-ben meghirdetett „Global Maritime Fulcrum” politikájának része a tengeri érdekeltségek védelméhez szükséges képességek fejlesztése. Jakarta számára 
az „elrettentés” igénye deklarált szempont. 2018-ban például a Natuna-szigeteken létrehozott új támaszpont kapcsán a védelmi minisztérium egyértelmüen hangsúlyozta annak elrettentő funkcióját a tengeri határvidéken tapasztalt agresszióval szemben, bár a nemzetközi elemzők közül van, aki további funkciók relevanciáját hangsúlyozza a támaszponttal kapcsolatban. ${ }^{27}$

Jakarta az ezredforduló óta képes volt fokozatosan igazítani védelempolitikáját a változó regionális kihívásokhoz. A korábban népi háborúra berendezkedett tömeghadsereg helyett egy modern, korszerü fegyverzettel felszerelt területvédelmi feladatú haderő kialakítása mellett kötelezte el magát a 2004-ben kihirdetett „Minimum Essential Force 2024” (MEF 2024) fejlesztési programmal. ${ }^{28}$ Ennek egyik legfontosabb és egyben legambiciózusabb törekvése, a haditengerészeti képességek fejlesztése a partvédő „barnavizi” realitásból egy tengeri elrettentésre képes haderőnem irányába, külön kiemelve az olyan tengeri aszimmetrikus elrettentési képességeket, mint az aknahadviselés vagy a tengeralattjárók. A fegyverrendszerek korszerüsítése mellett jelzi a MEF 2024 stratégiai irányait, hogy a haditengerészet létszáma a 2008-as 45 ezer föről 2020-ra 65 ezerre nőtt.

Indonézia haditengerészetének hajóparkja komoly átalakuláson esett át az elmúlt években. A 2000-es évek elején a flotta fö csapásmérő erejét két elavult, kiképzésre használt Cakra-osztályú tengeralattjáró (német Type 209/1300) jelentette. Az ezredfordulót követően az egységeket Dél-Koreában korszerüsítették. A típust szintén rendszeresítő Szöul az 1990-es években megvásárolta tengeralattjárógyártási licenszét, amelyet a Daewoo vezette hajóépítő konzorcium alaposan áttervezett, létrehozva ezzel a jelentősen korszerüsített Chang Bogo osztályt. ${ }^{29}$ Indonézia a típus továbbfejlesztett változatából, a Nagapasa osztályból három egységet állított hadrendbe, további hármat pedig megrendelt, bár 2020 áprilisában - költségvetési okokból - felvetődött a szerződés felmondása. ${ }^{30}$

A felszíni flotta az ezredfordulón még jellemző elavult hajóparkkal rendelkezett, ezek kivonása folyamatosan zajlik, és új, korszerủ fegyverzettel felszerelt típusokra cserélik. Jelenleg 11 fregatt áll hadrendben, hat Ahmad Yani osztályú, holland gyártmányú hajóegység (Van Speijk osztály), illetve 4 Diponegoro és 2 R.E. Martadinata osztályú, utóbbi két típus a holland fejlesztésü SIGMA moduláris hajótípus különböző feladatkörre optimalizált változatai. ${ }^{31} \mathrm{~A}$ fregattok, csakúgy mint a korvettek többsége is, korszerü hajó elleni és légvédelmi rakétákkal, valamint ASW-fegyverrendszerekkel vannak felszerelve.

Indonézia jelenleg nem rendelkezik tengeri járőrrepülőgépekkel, ami korlátozza a tengeralattjáró elleni hadviselési képességeit is, ezért az elmúlt években az erre irányuló beszerzések is megnövekedtek (8. táblázat).

\footnotetext{
27 Evan Laksmana: Why Indonesia’s new Natuna Base is not about deterring China. [online], 2019. 01. 25. Forrás: amti.csis. com [2021. 04. 13.]

28 Benjamin Schreer: Moving beyond ambitions? Indonesia's military modernisation. Australian Strategic Policy Institute, 2013.

29 Franz-Stefan Gady: South Korea launches first Indonesian stealth submarine. [online], 2016. 03. 29. Forrás: thediplomat. com [2021. 04. 13.]

30 Franz-Stefan Gady: Indonesia is reconsidering contract with South Korea for 3 diesel-electric submarines. [online], 2020. 04. 03. Forrás: thediplomat.com [2021. 04. 13.]

31 Naval Technology: SIGMA-Class Corvettes. [online], Forrás: naval-technology.com [2021. 04. 13.]
} 


\section{8. táblázat: Indonézia vadászgép-, vadászbombázó- és ASW-eszközparkjának típusai 2008-ban és 2020-ban}

\begin{tabular}{|l|c|c|}
\hline Indonézia & $\mathbf{2 0 0 8}$ & $\mathbf{2 0 2 0}$ \\
\hline Su-27 & 2 & 5 \\
\hline F-16 & 10 & 33 \\
\hline F-5 & 12 & 0 \\
\hline Su-30 & 2 & 11 \\
\hline A-4 & 11 & 0 \\
\hline Hawk Mk108 & 35 & 0 \\
\hline HAS-1 Wasp & 9 & 0 \\
\hline Eurocopter AS565 Panther & 0 & 10 \\
\hline
\end{tabular}

Forrás: a szerző szerkesztése az International Institute of Strategic Studies: The Military Balance évkönyvek (2008-2020) adatainak összesítése alapján

A vizsgált korszakban Indonézia vadász- és csapásmérő repülőgép-állományából, hasonlóan a többi vizsgált délkelet-ázsiai országhoz, az elavultabb géptípusokat fokozatosan kivonták. Ezeket fokozatosan, de arányaiban jóval kisebb mértékben váltották/váltják fel a korszerübb típusok, kiemelendő az orosz Szu-30-asok és az amerikai F-16-osok beszerzése. Ugyanakkor azt le kell szögezni, hogy az ország méretéhez és népességéhez, illetve a kínai fenyegetés nagyságához képest - hasonlóan a Fülöp-szigetekhez - ez a géppark nem elegendő.

\section{Haditengerészeti képességek változásainak általános trendjei}

A vizsgált adatok és országspecifikus sajátosságok alapján az eltérő adottságok és a haderők különböző intézményi, valamint politikai öröksége mellett is látható néhány általános trend a haditengerészeti és egyéb kiegészítő képességek fejlődésére vonatkozóan.

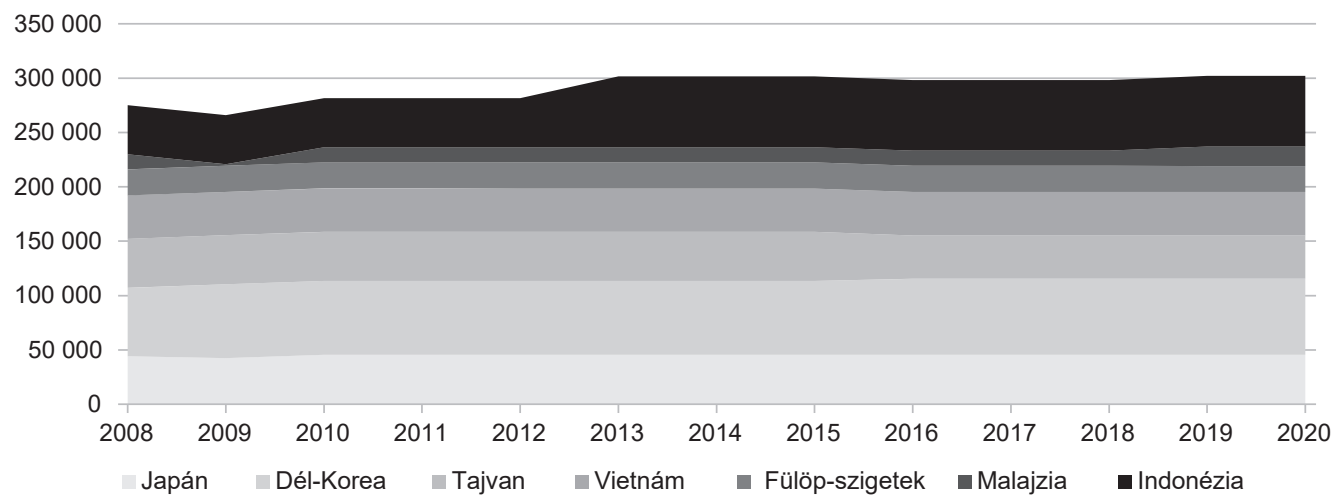

1. ábra: A régió haditengerészeti személyi állományának változása 2008-2020 között

Forrás: a szerző szerkesztése az International Institute of Strategic Studies: The Military Balance évkönyvek (2008-2020) adatainak összesítése alapján 
A haditengerészet mint haderőnem regionális jelentőségét mutatja, hogy a különböző haderőreformok, korszerűsítési programok keretében zajló - a fegyveres erőknél megfigyelhető - számottevő állománycsökkentés nem érintette jelentősen a vizsgált országok haditengerészeteit. Sőt, esetenként akár óvatos növekedést is történt e haderőnemek esetén (1. ábra).

A nagyobb felszíni hajóegységek és hagyományos meghajtású támadó tengeralattjárók összesített száma nőtt, illetve zajlott az elavult eszközök korszerü típusokkal történő leváltása. Míg 2008-ban akár még II. világháborús eredetű fregatt is tarkította a regionális hajótípusok összképét, mára egy komoly minőségi javulásnak lehetünk szemtanúi. Elvétve ugyan még hadrendben állnak a hidegháború első felében vízre bocsátott hajóegységek, azonban a legtöbb vizsgált ország esetében a 2008-2020 közötti időszakban sikerült a felszíni hajópark derékhadát az ezredforduló utáni technológiai színvonalat képviselő típusokra cserélni. Japán és Dél-Korea kivételével azonban ez általában külföldi beszerzésekkel, vagy jelentős külföldi technológiai és beszállítói segítséggel tudott megvalósulni. Tokió és Szöul ráadásul jelentős - teljesen, illetve zömében saját fejlesztésű és gyártású - támadó tengeralattjáró eszközparkkal rendelkezik, míg a többi ország esetében ez a képesség mind minőségében, mind mennyiségében jóval korlátozottabb. Azonban Vietnám elmúlt évtizedes fejlesztései, Tajvan a tervezés fázisában járó hazai fejlesztésű tengeralattjáró-programja, illetve a többi ország közelgő beszerzései is jól jelzik, hogy regionális szinten várható a tengeralattjárók mennyiségének és minőségének alapos növelése.

Mind a felszíni hajóegységek, mind a tengeralattjárók, illetve az ASW-repülőeszközök, illetve a partiőrségek hajóállománya kapcsán megemlíthető, hogy az elmúlt évtized fejlesztéseinek és növekvő beszerzéseinek köszönhetően, továbbá a többi országhoz képest sokkal jelentékenyebb hadiipari és védelmi kutatás-fejlesztési potenciálja révén, Dél-Korea és Japán fokozatosan egyre jelentősebb beszállítókká válnak a régión belül (2. ábra).

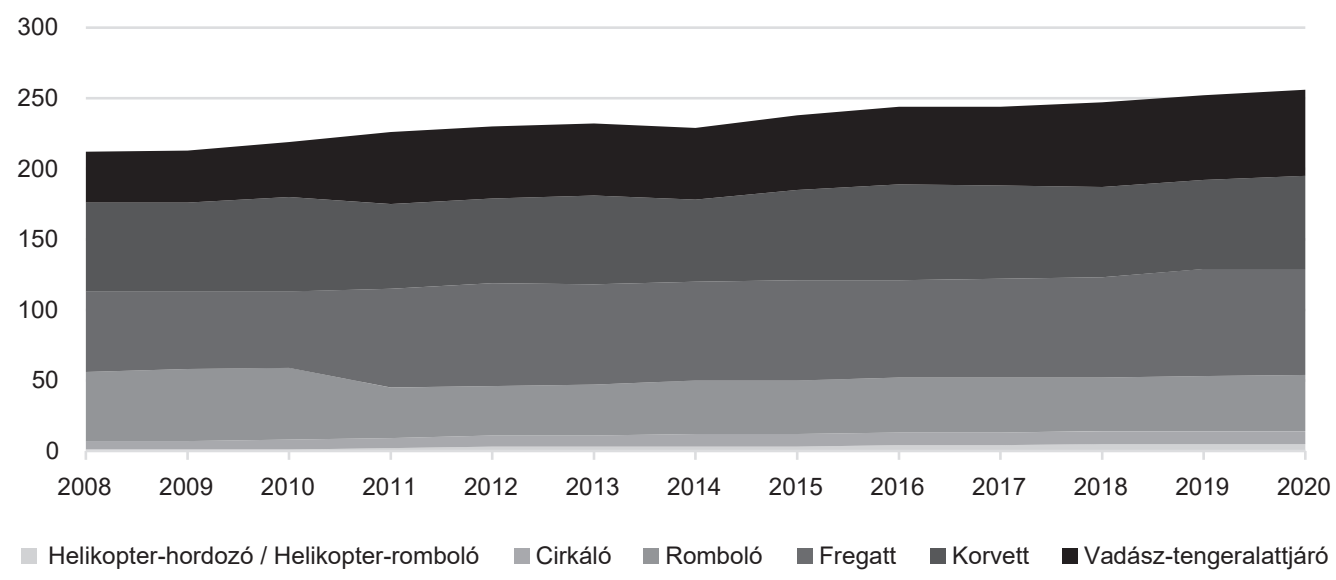

2. ábra: A nagyobb felszíni hajóegységek, illetve támadó tengeralattjárók száma 2008-2020 között

Forrás: a szerző szerkesztése az International Institute of Strategic Studies: The Military Balance évkönyvek (2008-2020) adatainak összesítése alapján 
Szintén a régió egészére jellemző trend, hogy a vizsgált időszakban nőtt azon országok köre, ahol nagy méretü, komolyabb kapacitású partraszállító hajó (esetleg több is) állt hadrendbe, illetve összességében nőtt az ilyen képességű eszközök száma. Ráadásul további országok helyezték kilátásba ilyen hajótípusok hadrendbe állítását.

Az ASW-feladatkörü repülőgépek száma összességében ugyan csökkent, ám egy általános korszerüsítési folyamat zajlott le, így ez nem feltétlenül jelenti ennek a képességnek a leértékelődését. Ráadásul nőtt azoknak a hajótípusoknak a száma, amelyek képesek fedélzetükön ASW-rendeltetésủ repülőeszközöket (helikopterek, pilóta nélküli repülőeszközök) üzemeltetni, így a tengeralattjáró elleni hadviselés képessége a regionális tengeri műveleti térben összességében bővült (3. ábra).

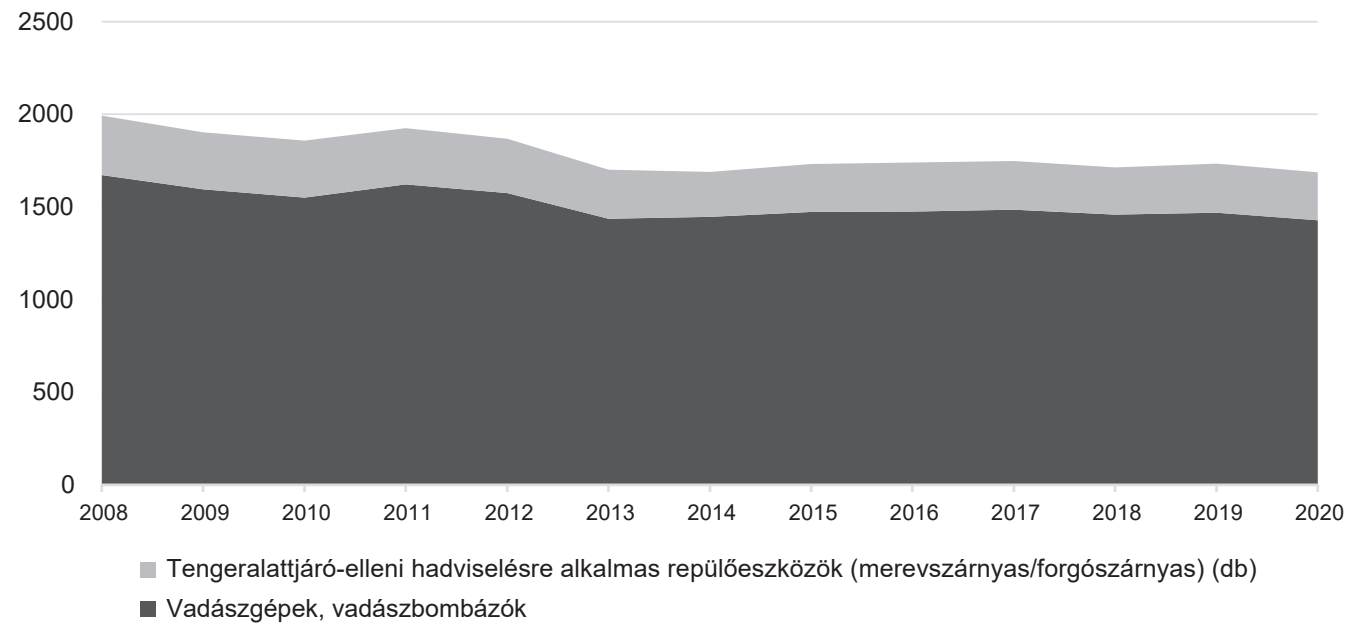

\section{3. ábra: A vadász- és támadó repülögépek, illetve ASW-repülöeszközök száma 2008-2020 között}

Forrás: a szerző szerkesztése az International Institute of Strategic Studies: The Military Balance évkönyvek (2008-2020) adatainak összesítése alapján

A haditengerészetek mellett szintén jelentős fejlesztéseken estek át egyes országok légierői. Bár a Military Balance összesítései alapján vadász- és támadó gépek (FTR, FTA), vadászbombázók (FGA), és felderítő szerepkörben üzemeltetett vadászgépek (RECCE, ISR) száma a vizsgált országok egészét tekintve összességében kis mértékben csökkent, jól látható trend az eszközparkok átfogó korszerüsítése és az elavult típusok fokozatos kivonása (4. ábra). 


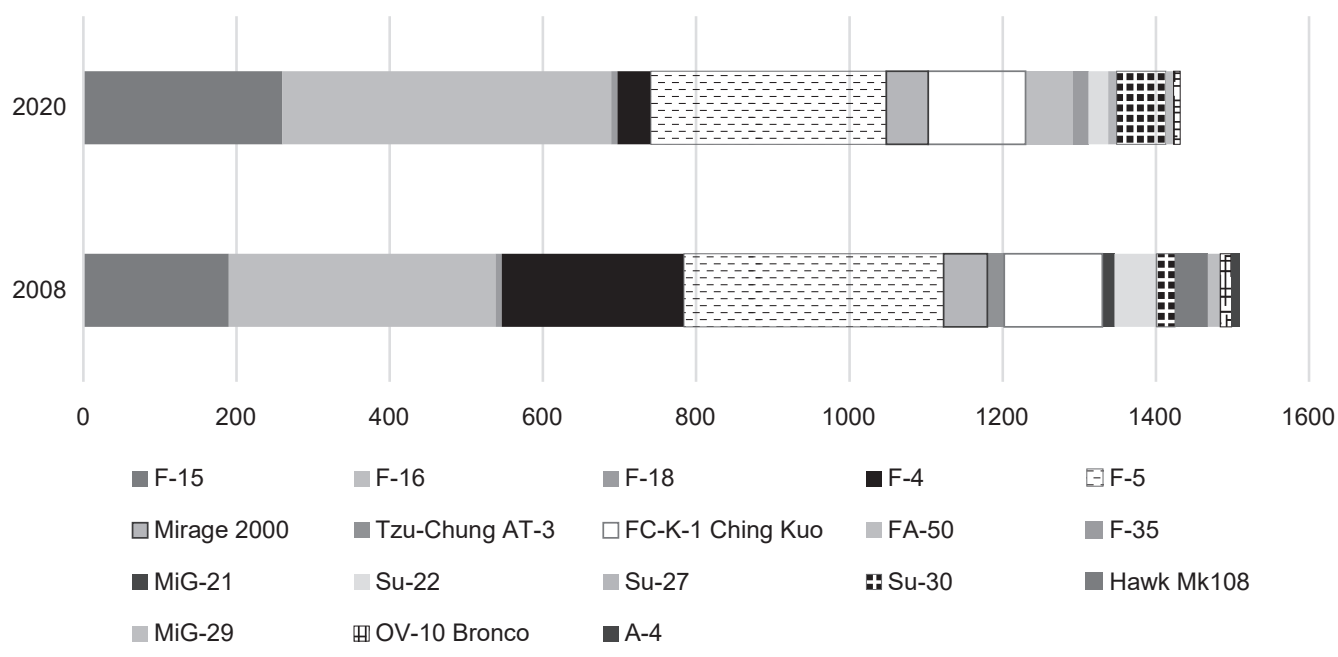

4. ábra: A vadász- és támadórepülőgép-parkok összetétele géptípusok alapján 2008-ban és 2020-ban

Forrás: a szerző szerkesztése az International Institute of Strategic Studies: The Military Balance évkönyvek (2008-2020) adatainak összesítése alapján

Ami kirívóan magas növekedést mutat, az a partiőrségek hajóállományának látványos gyarapodása. Egyértelmüen látszik, hogy a haditengerészeti kapacitások fokozatos növekedése mellett a régióban a „szürke zónás” incidensek szempontjából fontos partiőrségi képességek fejlesztése is kiemelt figyelmet élvez (5. ábra).

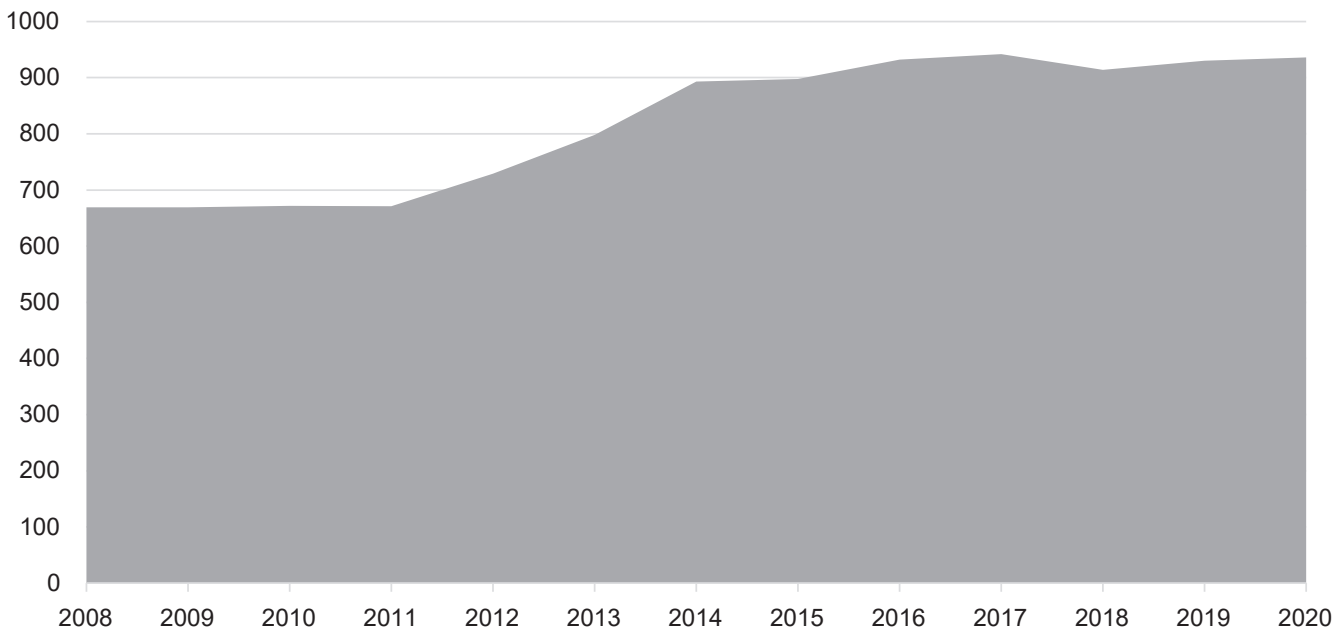

\section{5. ábra: A partiörségek hajóegységeinek száma 2008-2020 között}

Forrás: a szerző szerkesztése az International Institute of Strategic Studies: The Military Balance évkönyvek (2008-2020) adatainak összesítése alapján 
Az elmúlt 12 év vonatkozó adatait vizsgálva, illetve számba véve az egyes országok védelempolitikáinak sajátosságait, megfigyelhető egy regionális fegyverkezési verseny, amelynek alább láthatjuk a jellegzetességeit:

A védelmi ráfordítások reálértékének lassú növekedése. Árnyalja a képet, hogy a források növekedése bizonyos képességrendszerek fejlesztésére koncentrál.

A felszíni hajóegységeknél:

Jelentősen nött a repülőgép- vagy pontosabban helikopterhordozók (2008: $1 \mathrm{db}-2020$ : $5 \mathrm{db}$ ), a cirkálók (2008: $6 \mathrm{db}-2020: 9 \mathrm{db}$ ) és a fregattok (2008: $57 \mathrm{db}-2020: 75 \mathrm{db}$ ) menynyisége. Ezzel párhuzamosan az elavult hajóosztályokat vagy korszerüsítették, vagy újabb magasabb harcértékủ egységekkel váltották fel, azaz a mennyiségi mellett minőségi növekedés is történt.

Kvantitatív szempontból látható a növekedés a felszíni hajóegységek terén is. A rombolók számában ugyan csökkenést láttunk (2008: 49 - $202040 \mathrm{db}$ ) azonban itt számottevő volt a korszerübb hajótípusok regionális terjedése. A fregattok számában a hasonló minőségi fejlődés mellett a mennyiségi növekedés is jelentős (2008: $57 \mathrm{db}-202075 \mathrm{db}$ ). A korvettek esetében (2008: $63 \mathrm{db}$ - 2020: $66 \mathrm{db}$ ), azonban itt is jelentős az eszközök minőségi javulása, például a légvédelmi képességek terén.

A legnagyobb növekedés a támadó tengeralattjárók számában mutatkozott, amely egyben jelentös korszerüsitéssel is járt.

A repülőeszközök esetében csökkent mind a vadász- és vadászbombázó repülőgépek száma (2008: $1672 \mathrm{db}$ - 2020: $1428 \mathrm{db}$ ), illetve a tengeralattjáró elleni hadviselésre (ASW), illetve tengeri járőrfeladatok ellátására alkalmas merev- és forgószárnyas eszközpark (2008: $321 \mathrm{db}-2020: 259 \mathrm{db}$ ). Azonban mindez itt is egy átfogó korszerüsítéssel párosult. Különösen az ASW-helikopterek műveleti lehetőségei bővültek széles körben az azok üzemeltetésére alkalmas fedélzetü felszíni hajóegységek számának általános növekedésével.

Számottevő növekedés következett be a partiőrségek hajóállományában is (2008: $669 \mathrm{db}$ - 2020: $936 \mathrm{db}$ ). Ez elsősorban az egyre gyakoribb „szürke zónás” incidensek kapcsán fontos ezek mennyisége, amely jól mutatja a biztonsági kihívásokra adott válaszokon keresztül, hogy a Kínával kapcsolatos fenyegetettségpercepciójú országok esetében a tengeri „hibrid hadviselés” elleni védekezés meghatározó kérdés.

Van néhány olyan haderőfejlesztési törekvés, amely nem jellemző a vizsgált országok egészére, de mégis érdemes kiemelni, mint egyes szereplők fontos védelmi törekvéseit:

A nagyobb méretü (ezzel együtt jelentősebb hatótávolságú és pusztító képességü) hajó elleni cirkálórakéták beszerzése, illetve adott esetben hazai fejlesztései. Ezek képességeiket tekintve még mindig nem mérhetők a kínai ASBM-eszközökhöz - mint például a DF-21D - azonban mégis némileg hasonló célúak, mint a kínai A2/AD koncepció egyik központi eleme. Hazai fejlesztésű eszközökkel Japán (Type-88 és Type-12), illetve Tajvan (Hsiung Feng I-III. széria) rendelkezik. Vietnám esetében ez az eszközrendszer orosz beszerzésre épül (SSC-1, SSC-3 és SSC-5).

Japán - pacifista védelempolitikája ellenére is - részesévé vált a hiperszónikus csapásmérő eszközök kapcsán zajló fegyverkezési versenynek. Ezenfelül a szigetország felderítőmühold-programja is számottevő, továbbá ürvédelmi képességeket is fejleszt. 
Dél-Korea és Japán releváns partra szállitó rohamhajó eszközparkkal rendelkeznek, ezek fejlesztése folyamatos, illetve mindkét ország esetében várható, hogy (partra szállító) helikopterhordozóként működő, vagy jelenleg fejlesztett könnyürepülögép-hordozóikon F-35B típusú vadászgépeket üzemeltetnek majd, tehát összességében komoly elköteleződést láthatunk a tengeri erőkivetítés irányába.

Ezek fényében összességében látszik, hogy a kínai haderő átfogó fejesztése, a Peking „határozott érdekérvényesítő politikája” kapcsán fenyegetettségpercepcióval rendelkező országok esetében az A2/AD törekvéseket emuláló, illetve a tengeri erőkivetítés vonatkozásában releváns képességek regionális terjedésével párosult. A régió országainak $\mathrm{A} 2 / \mathrm{AD}$ törekvéseivel foglalkozó elemzések száma az utóbbi években megnőtt, mind a biztonságpolitika, mind a védelempolitika nemzetközi szakirodalmában, azt sugallva, hogy az USA e regionális törekvések támogatásával csökkenthetné Kína mozgásterét, ${ }^{32} \mathrm{~s}$ hasonló tartalmú anyagok jelentek meg a tematikus angol nyelvü médiában. ${ }^{33}$ De talán még jobban jelzi ennek relevanciáját, hogy ma már például Japán $\mathrm{A} 2 / \mathrm{AD}$ stratégiájával foglalkozó kínai írásokkal is találkozhatunk. ${ }^{34}$

Jelen tanulmány elsősorban e folyamatok számszerűsíthető trendjeit, illetve az eszközparkok modernizációinak kvalitatív folyamatait igyekezett nyomon követni. További figyelmet érdemelne annak vizsgálata, hogy milyen mélységű regionális biztonsági kooperáció tapasztalható a vizsgált országok, illetve más érintett felek között. Ennek feldolgozása túlmutat jelen írás keretein, azonban Japán és Dél-Korea egyre jelentősebb regionális védelmi exportja talán érintőlegesen jelzi a térségben zajló biztonságpolitikai folyamatokban a korábban nem tapasztalt integráció óvatos jeleit.

\section{Konklúzió}

Kelet-Ázsia egyértelmű jeleit mutatja egy regionális fegyverkezési versenynek, amelynek egy komoly mozgatórugója a Kínai Népköztársaság katonai képességeinek folyamatos növekedése.

Hét választott ország esetében vizsgáltam meg, hogy a tengeri műveleti térrel kapcsolatos elrettentési képességek hogyan változtak meg. Prekoncepcióként él a vonatkozó szakirodalomban, hogy Kína az ezredfordulót követően kialakult aszimmetrikus tengeri elrettentés stratégiai koncepciójának bizonyos elemei haderőfejlesztési irányként visszaköszönhetnek majd az egyre növekvő kínai haditengerészeti képességekre reagáló regionális szereplők esetében. Ezt alátámasztják az itt vizsgált tényezők és leírt regionális trendek.

Regionális trendként említendő mind a vizsgált fegyverrendszerek kvantitatív növekedése - változó, de többségében szignifikáns mértékben -, valamint az eszközparkok kvalitatív javulása, korszerüsítése. Amely esetben csökkent az eszközök száma, rendszerint

\footnotetext{
32 Eugene Gholz - Benjamin Friedman - and Enea Gjoza: Defensive defense: A better way to protect US allies in Asia. The Washington Quarterly, 42. (2019), 4. 171-189.

33 The National Interest: Time to Use China's A2/AD Military Strategy Against Them. [online], 2019. 01. 20. Forrás: nationalinterest.org [2021. 04. 13.]

34 Sina: 日本抹黑中国反介入战略 现在却要用该战略对抗中国. [online], 2017. 04. 21. Forrás: mil.sina.cn [2021. 04. 13.]
} 
ezzel párhuzamosan modern, fejlett, nagyobb harcértékü típusok váltották kisebb számban a kivont korszerütlen típusokat.

A tengeri elrettentés koncepcióinak párhuzamai a hasonló kínai törekvésekkel néhány ország esetében kiterjedtek jelentős hajó elleni rakéta eszközpark fejlesztésére vagy beszerzésére, repülőgép-hordozók fejlesztésére, illetve számottevő partra szállító kapacitás kiépítésére.

A tengeri műveleti térrel kapcsolatos elrettentési képességek (felszíni hajók, tengeralattjárók, hajó elleni cirkálórakéták), valamint erőkivetítési képességek (repülőgép-hordozó, partraszállító rohamhajók) terén a legjelentősebb regionális szereplő Japán. A szigetország tengeri haderőneme, a JMSDF bizonyos képességek terén paritásban mérhető Kínával, a cirkálók és rombolók száma 2020-ban kevéssel még meg is haladta a kínai eszközökét. A szigetország ezeken túl további számottevő katonai képességek fejlesztésébe kezdett.

Kína jelenlegi érdekérvényesítésének a sok közül egy eleme fegyveres erőinek reformja, katonai képességeinek javítása. Ez azonban nem értelmezhető „légüres térben”, de még pusztán csak más nagyhatalmakkal - például az Egyesült Államokkal - összevetve is hiányos összképet kapunk, ha mellőzzük a regionális szereplőket. Ami látható, az az, hogy a Kína körüli országok közül többen is részt vesznek a regionális fegyverkezési versenyben, olyan képességeket fejlesztve, amelyek összességében tompítják Kína katonai fölényéböl adódó relatív előnyét, mivel a tengeri müveleti térben jelentősen bővül a releváns eszközrendszerek száma, illetve átfogó trendként zajlik azok modernizációja.

Ez a fegyverkezési trend vélhetően megmarad a közeljövőben is, így a későbbiekben érdemes lehet majd frissíteni erről alkotott képünket, újból górcső alá véve nem csupán Kína, de a régió érintett országainak változó védelempolitikáit.

$\mathrm{Az}$ elemzéshez használt táblázatok és grafikonok az International Institute of Strategic Studies: The Military Balance évkönyvek, az egyes országokra vonatkozó adatsorai alapján készültek. Ehhez a szerző az alábbi évkönyveket használta fel:

International Institute of Strategic Studies: The Military Balance 2008. Routledge, 2008. International Institute of Strategic Studies: The Military Balance 2009. Routledge, 2009. International Institute of Strategic Studies: The Military Balance 2010. Routledge, 2010. International Institute of Strategic Studies: The Military Balance 2011. Routledge, 2011. International Institute of Strategic Studies: The Military Balance 2012. Routledge, 2012. International Institute of Strategic Studies: The Military Balance 2013. Routledge, 2013. International Institute of Strategic Studies: The Military Balance 2014. Routledge, 2014. International Institute of Strategic Studies: The Military Balance 2015. Routledge, 2015. International Institute of Strategic Studies: The Military Balance 2016. Routledge, 2016. International Institute of Strategic Studies: The Military Balance 2017. Routledge, 2017. International Institute of Strategic Studies: The Military Balance 2018. Routledge, 2018. International Institute of Strategic Studies: The Military Balance 2019. Routledge, 2019. International Institute of Strategic Studies: The Military Balance 2020 Routledge, 2020. 


\section{Felhasznált irodalom}

Airforce Technology: FA-50 Light Combat Aircraft. [online], Forrás: airforce-technology.com [2021. 04. 13.]

Chang, Felix K.: Resist and Reward: Vietnam's Naval Expansion. [online], 2019. 11. 06. Forrás: fpri.org [2021. 04. 13.]

CIA The World Factbook: The Philippines. [online], 2021. 06. 29. Forrás: cia.gov [2021. 04. 13.]

Csoma Mózes: Korea: egy nemzet, két ország-a közös gyökerektöl. Budapest, Napvilág, 2016.

Defense World: Vietnam Launches Two Home-made Molniya-class Missile Corvettes. [online], 2017. 10. 12. Forrás: defenseworld.net [2021. 04. 13.]

Department of National Defense of the Philippines: Revised Armed Forces of the Philippines Modernization Act. [online], Forrás: dnd.gov.ph [2021. 04. 13.]

Gady, Franz-Stefan: South Korea launches first Indonesian stealth submarine. [online], 2016. 03. 29. Forrás: thediplomat.com [2021. 04. 13.]

Gady, Franz-Stefan: Indonesia is reconsidering contract with South Korea for 3 diesel-electric submarines. [online], 2020. 04. 03. Forrás: thediplomat.com [2021. 04. 13.]

Gholz, Eugene - Benjamin Friedman - and Enea Gjoza: Defensive defense: A better way to protect US allies in Asia. The Washington Quarterly, 42. (2019), 4. 171-189. Online: https://doi.org/10.1080/0163660X.2019.1693103

Grønning, Bjørn Elias Mikalsen: Japan's security cooperation with the Philippines and Vietnam. The Pacific Review, 31. (2018), 4. 533-552. Online: https://doi.org/10.1080/09512748.2017.1397730

The Japan Times: Japan and Vietnam ink first maritime patrol ship deal. [online], 2020. 08. 11. Forrás: japantimes. co.jp [2021. 04. 13.]

Laksmana, Evan: Why Indonesia's new Natuna Base is not about deterring China. [online], 2019. 01. 25. Forrás: amti.csis.com [2021. 04. 13.]

Navy Recognition: Navy of Philippines will order two new Pohang-class corvettes from South Korea. [online], 2019. 08. Forrás: navyrecognition.com [2021. 04. 13.]

Olson, Wyatt: US to give Vietnam another coast guard cutter amid rising tensions in South China Sea. [online], 2019. 11. 21. Forrás: stripes.com [2021. 04. 13.]

The National Interest: Time to Use China's A2/AD Military Strategy Against Them. [online], 2019. 01. 20. Forrás: nationalinterest.org [2021. 04. 13.]

Naval Technology: SIGMA-Class Corvettes. [online], Forrás: naval-technology.com [2021. 04. 13.]

Nepomuceno, Priam: WW2-era BRP Rajah Humabon to be turned into a museum exhibit. [online], 2018. 03. 16. Forrás: pna.gov.ph [2021. 04. 13.]

Nepomuceno, Priam: Navy’s anti-sub choppers to be operational in November. [online], 2020. 01. 16. Forrás: pna. gov.ph [2021. 04. 13.]

Nepomuceno, Priam: Submarine acquisition among Navy's priorities. [online], 2020. 03. 04. Forrás: pna.gov.ph [2021. 04. 13.]

The Saigon Times: Vietnam joins AIIB to seek new funding source. [online], 2015. 06. 30. Forrás: english. thesaigontimes.vn [2021. 04. 13.]

Saunders, Stephen: Jane's Fighting Ships 2009-2010. Coulsdon, Surrey, UK, IHS Jane's, 2009.

Parameswaran, Prashanth: Defense Policy Dialogue Highlihgt Vietnam-Australia security ties. [online], 2019. 11. 04. Forrás: thediplomat.com [2021. 04. 13.]

Peragovics Tamás. Új status quo a Dél-kínai-tengeren?: Kína mesterségessziget-építésének hatásai a régió biztonságára. Nemzet és Biztonság, 10. (2016), 3. 58-74.

Pham, Bac - Chris Humphrey: US navy aircraft carrier Theodore Roosevelt to visit Vietnam as South China Sea tensions simmer. [online], 2020. 03. 04. Forrás: scmp.com [2021. 04. 13.]

Schreer, Benjamin: Moving beyond ambitions? Indonesia's military modernisation. Australian Strategic Policy Institute, 2013. [2021. 04. 13.]

Sina: 日本抹黑中国反介入战略 现在却要用该战略对抗中国. [online], 2017. 04. 21. Forrás: mil.sina.cn [2021. 04. 13.]

Naval Technology: Jose Rizal-Class Frigates, Philippines. [online], Forrás: navaltechnology.com [2021. 04. 13.]

The Saigon Times: Vietnam joins AIIB to seek new funding source. [online], 2015. 06. 30. Forrás: english. thesaigontimes.vn [2021.04. 13.] 
Saunders, Stephen: Jane's Fighting Ships 2009-2010. Coulsdon, Surrey, UK, IHS Jane's, 2009.

Stempler, Adam: The South China Sea Dispute between China and the Philippines. In Marcin Grabowski - Ewa Trojnar - Olga Barbasiewicz (eds.): Security dilemmas and challenges in $21^{\text {st }}$ century Asia. Berlin, Peter Lang, 2020. 83-102. Online: https://doi.org/10.3726/b17044

Yeo, Mike: Malaysia points to top concerns in first-ever defense whitepaper. [online], 2019. 12. 03. Forrás: defensenews.com [2021. 04. 13.]

Yeo, Mike: Malaysia to launch competition for drones and manned maritime patrol aircraft. [online], 2020. 08. 25. Forrás: defensenews.com [2021. 04. 13.]

Yoshihara, Toshi. „China's vision of its seascape: the first island chain and Chinese seapower." Asian politics \& Policy, 4. (2012), 3. 293-314. Online: https://doi.org/10.1111/j.1943-0787.2012.01349.x 